\title{
Reconstruction of Criminal Law Protection Policy for Credit Consumers Based on Financial Technology
}

\author{
Eko Raharjo ${ }^{1}$, Emilia Susanti ${ }^{2}$ \\ \{eko.raharjo3@gmail.com ${ }^{1}$, amild.wantara@gmail.com² ${ }^{2}$, \\ Faculty of Law University of Lampung, Indonesia ${ }^{12}$
}

\begin{abstract}
The development of fintech online loan business is currently growing rapidly in Indonesia. The use of online-based loans has become a breakthrough in economic development in Indonesia by providing easy loan services, but on the other hand fintech costumers are vulnerable to become victims of cybercrime such as threats, intimidation, fraud and misuse of personal data. The Efforts to protect costumers from organizing online loans based on POJK No. 1 / POJK.07 / 2013, POJK No. 77 / POJK.01 / 2016, and SEOJK Number 18 / SEOJK.02 / 2017. Therefore an ideal construction is needed in the protection of criminal law for fintech customers. This type of research is normative juridical and empirical juridical involving Lampung Financial Services Authority, Lampung Regional Police, and Lampung DISKOMINFO. The results of this study in the perspective of legal reform need to be made legal protection regulations provided to fintech costumers which include preventive legal protection and repressive legal protection based on the 2013 POJK and 2016 POJK as well as regulations related to the implementation of online-based fintech loans because they cannot currently provide protection maximum in the aspect of protection of criminal law so that it is necessary to make a special legislation policy that regulates related to the protection and implementation of fintech and the need for supervision that is carried out integrally by related agencies such as the Authority, KOMINFO, Police against illegal fintech.
\end{abstract}

Keywords: Policy; Protection; Criminal Law; Fintech Consumers; Financial Technology

\section{Introduction}

Technological developments have an impact on the higher economic growth in a country. . One form of economic progress as a result of technological developments is the development of online-based financial business (financial technology). Digital economic developments led to service innovations in various fields, one of them is the business of lending and borrowing money based on financial technology (PM-Tekfin). Based on the NDRC (The National Digital Research Center) Fintech is an innovation in the financial sector that gets a touch of technology and brings a more practical and secure financial transaction process .

The fintech business presents payment system services which include lending and borrowing services between parties in the community and public capital services. The fintech payment business is regulated and supervised by Bank Indonesia (BI), while the fintech lending and capital fintech business is overseen by the Financial Services Authority (OJK). Bank Indonesia (BI) classifies fintech into 4 categories, namely: (1) Payment, settlement, and clearing, is the fintech category that provides payment system services performed by banks and BI. (2) Market aggregator, is fintech that presents financial data so that users can use it as 
a comparison to choose the right financial product, (3) Risk and investment management, namely fintech which functions like a financial planner for users, (4) Peer to Peer Lending (P2P Lending) is a fintech offering direct loans to users at fixed rates.

One of fintech business that develops in Indonesia is Fintech Peer-to-peer (P2P) lending or what is referred to online-based. Fintech Peer-to-peer lending is a method of lending money to individuals or businesses and vice versa through applications that connect investors and borrowers online, peer to peer landing allows anyone to lend or apply for one another for various purposes without going through a legitimate financial institution as an intermediary. .

The rise of the online business in addition to having a positive impact also a negative impact, according to Jakarta Legal Aid there are 283 victims complaining about various forms of legal customers. The weakness of costumers' protection raises complex problems in several studies. It is known that the management of the financial system based on technology has not been able to provide effective protection considering when there are violations committed by parties concerned with fintech imposing criminal sanctions currently still using Law No. 19 of 2016 concerning ITE Law, namely Article 26 Paragraph 1, Article 27 and Article 29 if it involves the misuse of personal data, fraud and threats. Furthermore, fraud can be handled through fraud articles in the Criminal Code (KUHP). However, in practice, online-based crime is often constrained by evidence. Another problem is that online loan providers have also been carried out by illegal fintech operators whose physical presence is unknown.

Based on the description above, the development of fintech in Indonesia has not been matched by regulations on the protection of criminal law against costumers, so that many people are victims of crime in the implementation of online-based. The urgency of an ideal criminal law protection policy for fintech costumers is urgently needed to ensure the optimization of fintech especially the online loan business for economic growth and financial inclusion in achieving a balance between the ease and flexibility of technology offered by fintech with aspects of consumer security and comfort.

Based on this description, this article will focus on the implementation of criminal law protection for fintech-based costumers credit loans in positive law in Indonesia today, and the ideal construction of implementing criminal law protection for fintech-based consumer loans in the perspective of renewal, so that effective, efficient and fair fintech costumers protection policies are obtained in order to realize economic development and financial services are easy and convenient for the community as well as measures to prevent potential disruptions to financial system stability in Indonesia.

\section{Methods}

The approach used in writing is a legal approach, namely studying the law as a social phenomenon associated with the organization of corporate programs in the field of financial services based on internet technology. This approach examines the law as a construction as well as protection from the social phenomena associated with fintech. In addition, in accordance with the scientific character of law as a practical science with authoritative nomology, a statutory approach is also used. Some data collections will be done through indepth interviews and focus group discussions with stakeholders in the field of electronic technology formation, IT expert, criminal law expert, and law enforcement (Lampung Regional Police). 
While legal materials are collected through identification, inventory, classification and systematization of legal materials according to research problems. Analysis of legal materials or data are carried out prescriptive-analytic, that is, examining legal concepts, legal principles, legal norms, and legal systems relating to the administration and development of government in the field of technology-based financial services, particularly fintech companies. Dogmatic legal perspective, analysis of legal materials are done by way of exposure and analysis of the content (structure) of applicable law, systematization of legal phenomena that are explained and analyzed, interpretations, and assessments of applicable law.

\section{Discussion}

\subsection{Criminal Legal Protection of Online Based Consumer in Positive Law in Indonesia}

The State of Indonesia is a state of law, reads Article 1 Paragraph (3) of the 1945 Constitution of the Republic of Indonesia, the duties and obligations of the State in providing legal protection for people who needs attention, it is legal protection for online customers. Based on the theory of legal protection proposed by Satjipto Rahardjo which in this theory explains that legal protection is to provide protection for human rights that have been harmed by the public in order to enjoy all the rights granted by law . Efforts to protect human rights are carried out in two ways, are:

1. Preventive Legal Protection

Protection provided by the government with the aim of preventing before the occurrence of violations. This is contained in legislation with the intent to prevent a violation and provide guidelines or limitations in carrying out an obligation.

2. Repressive Legal Protection

Repressive legal protection is the final protection in the form of sanctions such as fines, imprisonment, and additional punishment given if a dispute has occurred or a violation has been committed.

Business activities in the era of the industrial revolution 4.0 generation has interfered with all aspects of human life and often cause legal problems, so that the state needs to play a role in protecting people as costumers, or service users of the business against the possibility of the occurrence of crimes in the course of the business. One of them is fintech Peer to Peer lending also called online-based. Based on the results of research conducted by researchers, it is known that in the operationalization of business activities fintech Lending or online-based currently there have been several violations of the consumer rights of users of online-based that are violated by the host company. The forms of violations can be seen in table 1.1 below:

Table 1. Data on violations against consumers caused by 2019 fintech

\begin{tabular}{|l|l|c|}
\hline No & \multicolumn{1}{|c|}{ Type of violation } & $\begin{array}{c}\text { Number of } \\
\text { Victims }\end{array}$ \\
\hline 1 & Very high interest rates without Limitation & 1145 \\
\hline 2 & $\begin{array}{l}\text { Billing not only to borrowers or emergency contact } \\
\text { numbers }\end{array}$ & 1100 \\
\hline 3 & $\begin{array}{l}\text { Distribution of photos and loan information to borrower } \\
\text { contacts }\end{array}$ & 903 \\
\hline 4 & Conduct threats, libel, sexual harassment and fraud & 781 \\
\hline 5 & Dissemination of personal data & 915 \\
\hline
\end{tabular}




\begin{tabular}{|l|l|c|}
\hline 6 & Unclear contact and location of online loans & 662 \\
\hline 7 & Unclear admin costs & 674 \\
\hline 8 & $\begin{array}{l}\text { The application is renamed without notice, while interest } \\
\text { continues to grow }\end{array}$ & 645 \\
\hline 9 & $\begin{array}{l}\text { The borrower has paid but the loan has not been written } \\
\text { off because the reason is not in the system }\end{array}$ & All \\
\hline 10 & Billing is done by different people & 2 \\
\hline 11 & $\begin{array}{l}\text { Personal identity card's data is used to borrow in other } \\
\text { applications }\end{array}$ & All \\
\hline 12 & $\begin{array}{l}\text { Virtual account returns incorrect, so interest continues to } \\
\text { grow }\end{array}$ & 7 \\
\hline 13 & $\begin{array}{l}\text { Retrieval of almost all information contained in the } \\
\text { borrower's smartphone }\end{array}$ & $\begin{array}{l}\text { Applications are renamed without notice while interest } \\
\text { continues to grow }\end{array}$ \\
\hline 14 &
\end{tabular}

Regarding the violations stated above, online-based costumers' loans are also vulnerable to becoming victims of crime. As for the types of violations that can be categorized as crimes are as follows:

1. First, credit crimes committed by corporate debtors who apply for credit by inflating the financial statements and good performance in order to get credit.

2. Second, prospective debtors have a tendency to bankrupt themselves.

3. Third, document falsification consisting of 2 types, namely bank guarantees and falsification of deposit bills.

4. Fourth, phishing or credit card identity theft, including crime of skimming or data theft through an account at an ATM.

5. Fifth, falsification of e-banking display (modified similar to the original and then deceived the customer when entering the password and username that is used primarily to move funds from the victim's account).

Related to the types of violations above based on the Focus Group Discussion (FGD) that has been conducted with the financial services authority, Dwi Krisno said that in fact the violations of the costumers rights of users of the fintech service Lending are often violated and most of the perpetrators are fintech Lending illegal, that's making it easier for businesses to pressure their customers who have not been able to pay off their debts with modes that conflict with existing laws, this is because at the time of making the fintech site peer to peer Lending is separated from the monitoring of his side because the financial services authority does not have the authority to supervise and close illegal and unilateral peer to peer Lending sites but must first propose site blocking to KOMINFO.

According to the Chairperson of the Investment Alert Task Force for Financial Services Authority, Tongam L Tobing said there needs to be a special law governing criminal acts against online loan services or illegal fintech's so that illegal and unregistered fintech's can be legally processed. Tongam revealed, during July 2019 to August 2019 the financial services authority had stopped 1,230 illegal fintech's. Of these, as many as 42 percent are not known the location of the server. Currently there are efforts to monitor and monitor illegal fintech's but there are still many illegal fintech's that continue to emerge and operate. 
The efforts made by Financial Services Authority to protect consumers from Fintech (P2P) illegal lending consists of two efforts, namely preventive and repressive efforts. This preventive effort is a protection that has the nature of prevention carried out by providing information and education related to the characteristics of the financial services sector by using digital outdoor space, social media, and outreach. Furthermore, through the Investment Alert Task Force formed by the Financial Services Authority which is tasked with preventing and stopping peer to peer Lending Illegal activities can take decisive actions that can protect peer to peer lending consumers are:

1. Announce to the public the names of peer to peer Lending Illegal so customers can know whether the website or online based loan application that they want to use is safe or not so that no further victims occur.

2. Disconnecting peer to peer Lending Illegal financial access to banks and fintech payment systems in collaboration with Bank Indonesia

While repressive measures are protections made after violations or disputes such as cracking down on peer to peer Lending Illegal and legal investment actors by applying sanctions that apply to existing regulations, settlement of complaints, termination of company activities or other administrative actions, and legal defense to protect costumers . Efforts to protect costumers from organizing online loans are regulated by special regulations made by OJK relating to aspects of consumer protection, including:

1. POJK No. 1 / POJK.07 / 2013 concerning costumers Protection in the Financial Services Sector. This provision especially applies to PUJK which has been overseen by the Financial Services Authority and carries out Fintech services. The PUJK must pay attention to all aspects of costumers' protection by applying the principles stipulated in article 2, namely the principles of transparency, fair treatment, reliability, confidentiality and security of costumers' data / information, and the use of costumers' complaints and settlement in a simple, fast and affordable cost.

2. POJK No. 77 / POJK.01 / 2016 concerning Information Technology and SEOJK Lending and Borrowing Services Number 18 / SEOJK.02 / 2017 concerning Information Technology Governance and Risk Management for Information Technology Lending and Borrowing.

Costumers' protection aspects regulated in peer to peer Lending by Financial Services Authority regulates the basic principles of user protection as in POJK No. 1 / POJK.07 / 2013 concerning costumers Protection in the Financial Services Sector, including:

1. The Organizer must provide and convey the latest information that is accurate, honest, clear and not misleading;

2. The organizer must use simple terms, phrases and or sentences in Indonesian that are easily read and understood by users in each electronic documents

3. The Operator is required to have standard operating procedures in serving users contained in electronic documents

4. The organizer is prohibited in any way from providing data and or information about users to third parties.

Regarding the protection of personal data on online based costumers loans, according to Permen PM 20/2016, is entitled to the confidentiality of his data. His data has the right to submit complaints in the context of resolving personal data sticky entitled to get access to obtain historical personal data and has the right to request the destruction of certain personal data of his person in the electronic system. According to Gunawan Sujadmiko, if a violation is committed through an online loan in the form of theft of personal data of the user of the provider and is disseminated without the consent of the costumers, then the action is a 
criminal action for a crime against a person's personal right to be kept confidential information about himself. As stated in Law No. 11 of 2008 concerning Electronic Information and Transactions, which includes protection from unauthorized use, protection by electronic system providers, and protection from illegal access and interference. Article 65 Paragraph 1-4 of Law No. 7 of 2014 concerning Trade therein also stipulates that "The use of an electronic system is required to meet the provisions stipulated in the ITE Law".

The data and / or information contains at least the following matters:

1. Identity and legality of the business actor as a producer or distribution business actor;

2. Technical requirements of the goods offered.

3. Technical requirements or qualifications of services offered;

4. Price and method of payment of goods and / or services;

5. How to deliver goods.

Rahmad Mardian said that in addition to the perpetrators of the theft of personal data of providers, users may be subject to articles in the ITE Law and can also be charged with Articles contained in the Criminal Code, namely. If the criminal act takes the form of physical violence and the taking of property, it may be subject to sanctions in accordance with Criminal Code Article 170 concerning violence, Article 351 concerning defamation, Article 368 Paragraph 1 concerning extortion and threats, Article 335 Paragraph 1 concerning forcing others to use violence.

\subsection{Ideal Construction that can be Used in Forming Special Arrangements Regarding Fintech}

The cases related to victims of fintech who are entangled in online as previously stated, make the public demand good and ideal regulations related to the implementation of online loans in order to protect the public and legal certainty from the bondage of "online moneylenders". The appropriate construction to be used in providing criminal law protection for fintech costumer is peer to peer lending, namely the PM-Tekfin Business must not be in conflict with Law Number 11 of 2008 concerning Information and Electronic Transactions. Legal protection that should be regulated includes criminal and civil legal protection in terms of business actors, consumers, products, and transactions in accordance with applicable laws. However, The Financial Services Authority cannot provide any other sanctions other than closing the company for illegal online loan service companies.

The regulation and supervision of PM-Tekfin's service business must also be based on;

1. Article 28 letter (F) and (G) Paragraph 1 of the 1945 Constitution;

2. Article 1 number 10, Article 5, Article 6 of Law Number 21 Year 2011 concerning the Financial Services Authority (OJK);

3. Law Number 11 Year 2008 concerning Information and Electronic Transactions (ITE)

4. Law Number 8 of 1999 concerning Consumer Protection;

5. Article 65 Paragraph (1 to 4 ) of Law Number 7 of 2014 concerning Trade;

6. Article 5 of Law Number 8 of 2010 concerning Money Laundering Crimes;

7. Law Number 30 of 1999 concerning Arbitration and Alternative Dispute Resolution;

8. Article 2 Paragraph (2) Regulation of the Financial Services Authority Number 77 / POJK.01 / 2016 concerning Information Technology Based Lending and Borrowing Services;

9. Article 2 Paragraph Regulation of the Financial Services Authority Number $1 /$ POJK.07 / 2013 concerning Consumer Protection of the Financial Services Sector; 
10. Article 1313, Article 1754 of the Civil Code (Civil Code) and Article 5, Article 170, Article 351, Article 368 Paragraph 1, Article 335 Paragraph 1 of the Criminal Code (KUHP).

There are needs to be a synergy of cooperation between the Ministry of Communication and Information Technology (Kominfo), the Financial Services Authority, and the police in overseeing online loan services. Currently the Financial Services Authority through its task force has made preventive measures against illegal online loan services. This was done by announcing a list of illegal online loan services to the public and then applying for blocking through the Ministry of Communication and Information to cut off financial access, and then submit a report to the police.

\section{Conclusion}

Based on the discussion above, it can be concluded that one form of fintech business that develops in Indonesia is Fintech Peer-to peer lending or what is referred to as online-based. Fintech Peer-to peer. Related to the implementation, there are often violations against consumers of fintech peer to peer lending users, therefore legal protection is needed for consumers of fintech users using peer to peer lending. The efforts was made to protect costumers from illegal peer to peer Lending consist of two efforts, namely preventive and repressive measures. This preventive effort is a protection that has the nature of prevention carried out by providing information and education related to the characteristics of the financial services sector by using outdoor digital space, social media, and outreach, Whereas repressive measures are protection carried out after violations or disputes such as cracking down on peer to peer legal lending and legal investment by implementing sanctions that apply to existing regulations, settlement of complaints, termination of company activities or other administrative actions, and legal defense to protect costumers.

Appropriate construction to be used in providing criminal law protection for fintech costumers of peer to peer lending, which must be in accordance with and must not be conflict with Law Number 11 of 2008 concerning Information and Electronic Transactions. Legal protection that should be regulated includes criminal and civil legal protection in terms of business actors, costumers, products, and transactions in accordance with applicable laws. The formation and regulation of PM-Tekfin's service business must be carried out based on laws relating to the implementation of fintech peer to peer lending. There needs to be a synergy of cooperation between the Ministry of Communication and Information Technology (Kominfo), the Financial Services Authority, and the police in overseeing online loan services. Increased digital literacy in the community. Considering that the negative impact of illegal online loan services is greatest in the community, there needs to be literacy to the public regarding digital / technology based. The public needs to know the provisions, impacts, and legal protection of these online loan transactions.

\section{References}

[1] Asosiasi Penyelenggara Jasa Internet Indonesia, 2016, "Intografis Penetrasi dan perilaku Pengguna Internet Indonesia, Jakarta

[2] Mansur, Didik M. arief dan Elisatris, 2009, Cyber Law Aspek Hukum Tehknologi Informasi, Bandung PT Refika Aditama.

[3] Mansur, Didik M. arief dan Elisatris, 2009, Cyber Law Aspek Hukum Tehknologi Informasi, Bandung PT Refika Aditama. 
[4] Sidabalok Janus, 2006, Hukum Perlindungan Konsumen di Indonesia, Bandung, Citra Aditya Bakti

[5] Sugona, Bambang. 2006. Metodelogi Penelitian Hukum, Jakarta Raja Grafindo, Persada

[6] Abdillah, Leon. "An Overview of Indonesian Fintech Application." In The First International Conference on Communication, Information Technology and Youth Study (I-CITYS2019), Bayview Hotel Melaka, Melaka (Malacca), Malaysia. 2019.

[7] Ayub Wicaksono, Dampak Tehknologi di Bidang Ekonomi "Kompasiana Blog,https:///www.kompasiana.com/ayyuub wicaksono-dampak-teknologi-di-bidangekonomi- 5114b97a33311bb43ba7d50 di aksespada 21 agustus 2019

[8] Azmi, Rama Halim Nur. "Indonesian Cyber Law Formulation in The Development Of National Laws In 4.0 Era." Lex Scientia Law Review 4, no. 1 (2020): 49-62.

[9] Basrowi, “Analisis Aspek dan Upaya Perlindungan konsumen Fintech Syariah” Lex Liberium jurnal Ilmu Hukum, 2019 diakses pada laman http://www. lexlibrum.id/index.php/lexlibrum/article/download/134/pdf.

[10] Batunanggar, Sukarela. Fintech development and regulatory frameworks in Indonesia. No. 1014. ADBI Working Paper Series, 2019.

[11] https://www.cnnindonesia.com/ekonomi/20190803030750-78-418018/ojk-minta-uukhusus-atur-pidana-fintech-ilegal

[12] https://www.investree.id/how-it-works, diakses pada tanggal 19 Oktober 2019.

[13] https://www.kompasiana.com/johanisalbertmalingkaspacaran/, Diakses pada tanggal 11 Oktober 2019.

[14] Iman, N., 2018. Assessing the dynamics of fintech in Indonesia. Investment Management and Financial Innovations, 15(4), pp.296-303.

[15] Pramana, I.W.B., Atmadja, I.B.P. and Sutama, I.B.P., 2018. Peranan Otoritas Jasa Keuangan Dalam Mengawasi Lembaga Keuangan Non Bank Berbasis Financial Technology Jenis Peer To Peer Lending. Kertha Semaya: Journal Ilmu Hukum, pp.114.

[16] Raharjo, A. and Sudrajat, T. eds., 2018, November. Fintech Indonesia User Legal Protection in Balance Borrowing Money Based on Information Technology. In SHS Web of Conferences (Vol. 54, p. 06003). EDP Sciences.

[17] Saputra, A.S., 2019. Peer To Peer Lending Di Indonesia Dan Beberapa Permasalahannya. Veritas et Justitia, 5(1), pp.238-261.

[18] Sugiarto, I. and Disemadi, H.S., 2020. Consumers Spiritual Rights In Indonesia: A Legal Study Of Sharia Fintech Implementation In The Consumers Protection Perspective. Jurnal IUS Kajian Hukum dan Keadilan, 8(3), pp.437-452.

[19] Koin works, ketahui tentang peer to peer lending, https://koin works.com/blog/ ketahui-tentang-peer-peer-lending/. Diakses tanggal 11 Oktober 2018.

[20] Subarsyah Sumadikara, Delik Hukum Fintech, https://www.pikiran-rakyat.com/luarnegeri diakses pada 7Agustus 2018 